\title{
Vrijeme za restrukturiranje Zagrebačkog holdinga
}

\author{
ANTO BAJO Institut za javne financije \\ MARKO PRIMORAC Ekonomski fakultet Zagreb
}

\begin{abstract}
Zagrebački holding treba restrukturirati, osloboditi pratećih djelatnosti i profilirati kao trgovačko društvo koje se bavi komunalnom djelatnošću. Dio postojećih djelatnosti Holdinga zapreka su razvoju tržišta, tržišnog natjecanjaipoduzetništva. Njegove tržišne djelatnosti proizvode gubitke, dodatno mu slabeći financijsku poziciju koja se može pogoršati bez ozbiljnog restrukturiranja.
\end{abstract}

\section{UVOD}

Zagrebački holding d.o.o. najveće je poduzeće $u$ vlasništvu lokalnih jedinica u Hrvatskoj. Financijsko poslovanje Holdinga je kontroverzno, a za širu zainteresiranu javnost njegova je stvarna financijska pozicija nepoznanica. Glavni je cilj ovoga rada utvrditi i ocijeniti financijsku poziciju Holdinga i naznačiti glavne financijske rizike u poslovanju. Analiza poslovanja Holdinga obavljena je za razdoblje 2006. - 20II. i temelji se na financijskim izvještajima. Za ocjenu kretanja prinosa na obveznice, korištene su informacije s Bloomberg sustava. U Skupštini Grada Zagreba 20. prosinca 2012. usvojeno je Izvješće o poslovanju Zagrebačkog holdinga za razdoblje siječanj-lipanj 20I2. Nažalost, nije korišteno $\mathrm{u}$ analizi jer nije javno dostupno.

\section{TEMELJNA DJELATNOST HOLDINGA}

Zagrebački holding d.o.o. osnovan je I. siječnja 2007. prijenosom poslovnih udjela i dionica 22 trgovačka društva s Grada Zagreba na trgovačko društvo Gradsko komunalno gospodarstvo d.o.o. Temeljem ugovora o prijenosu (od 27. 12. 2005.) Grad Zagreb je pretvaranjem potraživanja povećao temeljni kapital društva, na više od 4 milijarde kuna. U društvu su od osnivanja provedene brojne statusne promjene. U 20I2. trgovačko društvo obuhvaća I8 podružnica. U vlasništvu Društva je i sedam trgovačkih društava i ustanova koje zajedno čine grupu Zagrebački holding. Društvo ima poslovne udjele $u$ šest profitnih i neprofitnih institucija. Grad je IOO\% vlasnik 25 društava, u jednom društvu (Zagreb plakat d.o.o) ima 5I\%, u dva društva 50\% udjela (Terme Zagreb i Apis d.o.o.), u dva (Vodoopskrbi i Zračna luka) ima oko 35\%, a I3\% u jednom društvu (Bicro biocentar d.o.o.). Zanimljivo, u 2006. obavljena je privatizacija poduzeća Vodoprivreda d.d. u kojem Holding danas ima 36,I\% udjela. Privatizacija Vodoprivrede obavljena je temeljem Zakona o vodama (NN I07/95), kojim je predviđena privatizacija najmanje $51 \%$ kapitala trgovačkih društava vodnog gospodarstva. Izmjenama i dopunama Zakona o vodama (NN 150/O5), privatizacija se trebala okončati do kraja 2006.

Djelatnosti Holdinga načelno su grupirane u tri poslovna područja: komunalne, prometne i tržišne djelatnosti. U njima je zaposleno više od I2 tisuća djelatnika, a zajedno s Direkcijom ${ }^{1}$ Holding broji oko I3 tisuća zaposlenih. Najviše je zaposlenih u komunalnim djelatnostima (oko 5,7 tisuća), zatim u prometnim (4,9 tisuća) i tržišnim (2,3 tisuće).

\footnotetext{
I Prema Pravilniku o organizaciji društava od 2009. u Direkciji su integrirane korporativne i upravljačke funkcije (Državni ured za reviziju, 2012.).
} 
Tablica I.

Broj zaposlenih u Holdingu od 2007. do 2010.

\begin{tabular}{|c|c|c|c|c|}
\hline Djelatnost & 2007. & 2008. & 2009. & 2010. \\
\hline Tržišna & I.84I & 2.317 & 2.358 & 2.346 \\
\hline Komunalna & $5.4 \mathrm{II}$ & 5.729 & $5.77 \mathrm{I}$ & 5.682 \\
\hline Prometna & 4.644 & 4.749 & 4.839 & 4.873 \\
\hline Ukupno zaposleni u djelatnosti & II. 896 & I2.795 & I2.968 & I2.9OI \\
\hline Direkcija & nd & nd & nd & I33 \\
\hline Ukupno Direkcija i djelatnosti & nd & nd & nd & I3.034 \\
\hline
\end{tabular}

Napomena: $n d$ - podaci nisu dostupni

Izvor: Zagrebački holding.

Treba napomenuti da poduzeća koja Holding klasificira kao prometna, Zakon o komunalnom gospodarstvu tretira kao komunalna. Osnovni cilj komunalnih poduzeća je pružanje javnih usluga i osiguranje pokrića rashoda s prihodima. Međutim, postojeća Holdingova društva u dijelu poslovanja značajno monopoliziraju tržište i subvencijama iz proračuna Grada izravno narušavaju tržišno natjecanje. Odredbe Zakona o komunalnom gospodarstvu ne odnose se na trgovačka društva u vlasništvu Holdinga koja obavljaju tržišne djelatnosti. Ta društva trebaju poslovati po odredbama Zakona o zaštiti tržišnog natjecanja (NN 79/og). Na primjer, Grad Zagreb osnivač je trgovačkog društva Zagreb plakat d.o.o. koje djeluje na tržištu vanjskog oglašavanja (jumbo plakata), a ujedno je i „regulator” koji utvrđuje mjesto i uvjete postavljanja i iznajmljivanja oglasnih prostora. Takva situacija nije poželjna i ne doprinosi razvitku tržišnog natjecanja i tržišnog gospodarstva (AZTN, 2007.).

Upitno je i postojanje društava koja obavljaju tržišnu djelatnost u Holdingovom portfelju. Godišnje izvješće Holdinga za 20II. jasno ukazuje da tržišne djelatnosti ne ostvaruju dobit, pa ih u procesu restrukturiranja valja „isključiti” iz temeljnih djelatnosti društva. S druge strane, nije jasno zašto je 2006. privatizirana Vodoprivreda.

\section{FINANGIJSKO POSLOVANJE}

Holding nema problema s prihodima poslovanja kojima redovito pokriva rashode poslovanja. To pokazuje da postoji izvjesna stabilnost u redovitom poslovanju. Poslovni prihodi uglavnom su stabilni, a znatnije se povećavaju (2I\%) u 2009. i to zbog povećanja prihoda od prodaje i distribucije plina te prihoda od gradnje i prodaje stanova. Međutim, 2009. zabilježen je rast materijalnih troškova od $40 \%$ (zbog povećanja prodaje stanova i poslovnih prostora, tj. povećanja troškova prodanih zaliha koji se kao troškovi računovodstveno evidentiraju tek u trenutku prodaje nekretnine). U 2010 . prihodi poslovanja se smanjuju, pa Holding ostvaruje gubitak od poslovnih aktivnosti i ukupan neto gubitak. Društvo u 20Io. i 20II. ostvaruje gubitak od 469, odnosno 334 milijuna kuna zbog visokih financijskih rashoda koji su nastali kao rezultat nerazboritog financijskog upravljanja i visokih troškova zaduživanja.

\section{Tablica 2}

Financijsko poslovanje Zagrebačkog holdinga od 2006. do 20II. (u mil. kn)

\begin{tabular}{|c|c|c|c|c|c|c|}
\hline & 2006. & 2007. & 2008. & 2009. & 2010. & 2011. \\
\hline Poslovni prihodi & 4.557 & 5.329 & 4.960 & 5.750 & 5.403 & 5.375 \\
\hline Poslovni rashodi & 4.460 & 5.244 & 4.930 & 5.495 & 5.509 & 5.315 \\
\hline Financijski prihodi & I25 & 193 & 302 & $2 \mathrm{I} 2$ & I25 & II2 \\
\hline Financijski rashodi & $\mathrm{I} 22$ & 229 & 286 & 403 & 479 & 499 \\
\hline Ukupni prihodi & 4.683 & $5 \cdot 522$ & 5.262 & 5.962 & 5.528 & 5.486 \\
\hline Ukupni rashodi & 4.582 & 5.473 & 5.216 & 5.898 & 5.988 & $5.8 \mathrm{I} 4$ \\
\hline Dobit/gubitak prije oporezivanja & IOO & 49 & 46 & 64 & $-46 I$ & -328 \\
\hline Porez na dobit & $-\mathrm{I} 8$ & $-\mathrm{II}$ & -17 & -25 & -8 & -6 \\
\hline Dobit/gubitak tekuće godine & 82 & 38 & 29 & 39 & -469 & -334 \\
\hline
\end{tabular}

Izvor: Zagrebački holding 
Početkom 2006. financijski prihodi veći su od financijskih rashoda, pa je ostvarena dobit iz financijskih aktivnosti². Međutim, do 20II. financijski prihodi smanjeni su IO\%, a financijski su rashodi rasli četiri puta. Glavni je izvor negativnog financijskog poslovanja nekontrolirani rast financijskih rashoda (v. tablica 3).
Međutim, novim zaduživanjima rastu prosječne ponderirane efektivne kamatne stope na instrumente $\mathrm{s}$ fiksnom kamatnom stopom (osim za izdane obveznice, čija je stopa fiksna jer se odnosi isključivo na jedno izdanje obveznica). Trošak kamata na instrumente duga izrazito je visok unatoč kvalitetnim instrumentima osiguranja duga koji uključuju i jamstvo Grada Zagreba.

\section{Tablica 3.}

Financijski rashodi Holdinga od 2006. do 20II. (u mil. kn)

\begin{tabular}{|c|c|c|c|c|c|c|c|}
\hline Br. & Stavka & 2006. & 2007. & 2008. & 2009. & 2010. & 2011. \\
\hline I. & Rashodi za kamate & 93,7 & I6o,I & $233, \mathrm{I}$ & 270,4 & 284,2 & 298,2 \\
\hline 2. & Negativne tečajne razlike & 27,5 & $67, \mathrm{I}$ & 30,2 & 27,0 & 82,9 & $\mathrm{I} 37,3$ \\
\hline 3. & Kamate po najmovima (leasing) & & & 9,9 & 73,8 & 58,3 & 60,0 \\
\hline 4. & Ostalo & 0,6 & $2, \mathrm{O}$ & 2,5 & 2,6 & 9,2 & $\mathrm{O}, \mathrm{O}$ \\
\hline 5. & Ukupno $(\mathrm{I}+2+3+4)$ & I2I, 8 & 229,2 & 275,7 & 373,9 & 434,6 & 495,5 \\
\hline 6. & Povezana društva & & & 0,8 & 2,4 & $\mathrm{I}, 7$ & $\mathrm{I}, 6$ \\
\hline 7. & Drugi rashodi & & & 9,7 & 28,0 & 42,9 & $\mathrm{I}, 8$ \\
\hline 8. & Ukupno & $\mathrm{I} 2 \mathrm{I}, 8$ & 229,2 & 286,2 & 403,4 & 479,3 & 498,9 \\
\hline
\end{tabular}

Napomena: Od 2008. prvih 5 stavaka u tablici odnosi se samo na financijske rashode iz odnosa s nepovezanim društvima, dok stavka 8 (ukupno financijski rashodi) obuhvaća ukupne financijske rashode iz odnosa s povezanim i nepovezanim društvima. Do 2008. takva klasifikacija (na financijske rashode iz odnosa s povezanim i nepovezanim društvima) nije dostupna, već su vrijednosti pojedinih stavki prikazane u ukupnom iznosu (kako iz odnosa s povezanim tako i s nepovezanim društvima).

Izvor: Zagrebački holding.

\section{Tablica 4.}

Prosječne ponderirane efektivne kamatne stope od 2008. do 20II. (u \%)

2008. 2009. 2010.

Instrumenti s promjenjivom kamatnom stopom

\begin{tabular}{|c|c|c|c|c|}
\hline Obveze temeljem financijskog najma & 7,50 & 5,16 & 3,84 & 4,16 \\
\hline Krediti i zajmovi & $7,5 \mathrm{I}$ & 5,30 & 4,64 & 5,08 \\
\hline
\end{tabular}

Instrumenti s fiksnom kamatnom stopom

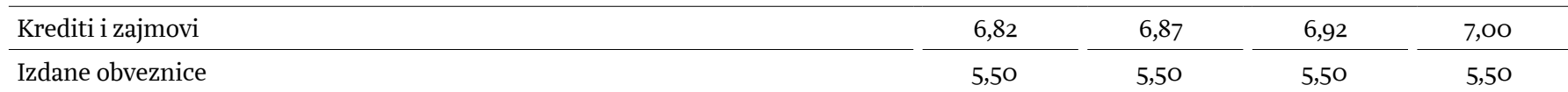

Izvor: Konsolidirani financijski izvještaji ZGH-a s izvještajem neovisnog revizora za 2009., 20Io. i 2011.

Ukupni financijski rashodi rastu na 499 milijuna kuna u 2OII. i to uglavnom zbog rasta rashoda za kamate i negativnih tečajnih razlika. Veliko su financijsko opterećenje i kamate po najmovima (leasingu) koji se odnose na opremu (prijevozna sredstva) i nekretnine (Arena Zagreb). Obveze Društva po najmovima osigurane su vlasništvom najmodavca nad imovinom. Prosječne ponderirane efektivne kamatne stope na instrumente $\mathrm{s}$ promjenjivom kamatnom stopom se smanjuju.

2 U 2008. financijski prihodi nadilazili su financijske rashode isključivo zbog prikazivanja prihoda od prodaje udjela (49\%) u Zagreb plakatu d.o.o. u iznosu od Iog milijuna kuna.

\section{PROBLEMI S UGOVORIMA O NAJMU}

Od 2009. revizorsko mišljenje o poslovanju Holdinga daje se s rezervom. Razlog je pogrešna klasifikacija ugovora o najmu koje je Holding sklopio tijekom 2008. i 2009., a koji su evidentirani kao operativni najam. Početna klasifikacija tih ugovora nije bila u skladu s Međunarodnim računovodstvenim standardom 17 „Najmovi”. MRS I7 najam klasificira kao financijski ukoliko je sadašnja vrijednost minimalnih budućih plaćanja po ugovoru približno jednaka fer vrijednosti imovine u najmu (što je bio slučaj s najmovima koje je 
Tablica 5.

Potencijalne posljedice ispravne klasifikacije ugovora o najmu (u mil. kn)

\begin{tabular}{|c|c|c|c|}
\hline Stavka & 2009. & 2010. & 2011. \\
\hline Potraživanja po financijskom najmu (+) & I.O39 & 899 & 773 \\
\hline Nekretnine, postrojenja i oprema (-) & I.I4O & I.066 & 982 \\
\hline Zadržani dobici (-) & 15 & 99 & I64 \\
\hline Dobitak (-)/gubitak (+) & 85 & 69 & 45 \\
\hline
\end{tabular}

Izvor: Konsolidirani financijski izvještaji ZGH-a s izvještajem neovisnog revizora za 20og., 20Io. i 2011.

sklopio Holding). Da je Holding ugovore o najmu evidentirao sukladno MRS-u I7 kao financijski najam, povećala bi se potraživanja po financijskom najmu (neto od zarađenog budućeg prihoda), a smanjila vrijednost nekretnina, postrojenja i opreme kao i zadržani dobici.

Da je Holding ispravno klasificirao ugovore o najmu (sklopljene tijekom 2008. i 2009.), u 2009. bi umjesto dobiti od 39, ostvario gubitak od 46 milijuna kuna. U narednim bi se godinama ostvareni gubitak uvećao za 69 milijuna kuna u 20Io. i 45 milijuna kuna u 2011. (v. tablicu 5).

Gubici Holdinga su u najvećem dijelu uzrokovani gubicima poslovanja podružnice ZET (na koju se odnose ugovori o najmu) te podružnica iz područja tržišne djelatnosti. Time se dodatno potvrđuje teza o potrebi restrukturiranja ZET-a i isključivanja iz Holdinga poduzeća iz područja tržišne djelatnosti. Dodatni razlozi povećanja financijskih rashoda mogu se dobiti uvidom u veličinu i strukturu financijskih obveza.

\section{VELIČINA I STRUKTURA FINANGIJSKIH OBVEZA}

Ukupne (dugoročne i kratkoročne) financijske obveze Holdinga (krediti, najmovi, financijski najmovi, obveznice i kamate) rastu s I,5 mlrd. u 2006. na 6,7 mlrd. kuna u 20II. Tako veliki rast obveza rezultat je izdanja 300 milijuna eura obveznica u 2007. i značajnog rasta kreditnih obveza. Prema podacima iz financijskih

\section{Tablica 6.}

Financijske obveze Holdinga od 2006. do 20II. (u mil. kn i \%)

\begin{tabular}{|c|c|c|c|c|c|c|c|}
\hline Br. & Stavka & 2006. & 2007. & 2008. & 2009. & 2010. & 2011. \\
\hline \multicolumn{8}{|c|}{ u mil. kn } \\
\hline I. & Dugoročne obveze $(2+3)$ & 1.299 & 3.683 & 5.126 & 5.970 & 5.673 & 5.431 \\
\hline 2. & prema kreditnim institucijama & I.299 & 1.485 & 2.923 & 3.754 & 3.457 & 3.172 \\
\hline 3. & za izdane vlastite obveznice & - & 2.198 & 2.203 & 2.216 & 2.216 & 2.259 \\
\hline 4. & Kratkoročne obveze $(5+6+7+8)$ & 224 & 498 & 537 & 545 & 995 & 1.270 \\
\hline 5. & krediti, zajmovi i financijski najam & 68 & 69 & 92 & 176 & 637 & 849 \\
\hline 6. & po izdanim vrijednosnim papirima & $2 \mathrm{I}$ & IO & 2 & - & - & - \\
\hline 7. & ostalo (obveze po kamatama) & - & 64 & 87 & 92 & 85 & 97 \\
\hline 8. & kratkoročni dio dugoročnih kredita & 135 & 356 & 355 & 277 & 273 & 325 \\
\hline 9. & Ukupne financijske obveze & I.523 & $4.18 I$ & 5.663 & 6.516 & 6.668 & 6.701 \\
\hline \multicolumn{8}{|c|}{ u \% ukupnih financijskih obveza } \\
\hline I. & Dugoročne obveze $(2+3)$ & 85,3 & $88, \mathrm{I}$ & 90,5 & 9I,6 & $85, \mathrm{I}$ & $8 \mathrm{I}, \mathrm{O}$ \\
\hline 2. & prema kreditnim institucijama & 85,3 & 35,5 & $5 I, 6$ & 57,6 & $5 \mathrm{I}, 8$ & 47,3 \\
\hline 3. & za izdane vlastite obveznice & - & 52,6 & 38,9 & 34,0 & 33,2 & 33,7 \\
\hline 4. & Kratkoročne obveze $(5+6+7+8)$ & $\mathrm{I} 4,7$ & II,9 & 9,5 & 8,4 & I4,9 & $\mathrm{I} 9, \mathrm{O}$ \\
\hline 5. & krediti, zajmovi i financijski najam & 4,5 & $\mathrm{I}, 6$ & $\mathrm{I}, 6$ & 2,7 & 9,6 & $\mathrm{I} 2,7$ \\
\hline 6. & po izdanim vrijednosnim papirima & $\mathrm{I}, 4$ & $\mathrm{O}, 2$ & $\mathrm{O}, \mathrm{O}$ & - & - & - \\
\hline 7. & ostalo (obveze po kamatama) & - & I,5 & $\mathrm{I}, 5$ & $\mathrm{I}, 4$ & 1,3 & $\mathrm{I}, 4$ \\
\hline 8. & kratkoročni dio dugoročnih kred. & 8,9 & 8,5 & 6,3 & 4,3 & $4, \mathrm{I}$ & 4,8 \\
\hline 9. & Ukupne financijske obveze & IOO & IOO & IOO & IOO & IOO & IOO \\
\hline
\end{tabular}

Izvor: Zagrebački holding 
izvještaja, sredstva prikupljena zaduživanjem prvo su deponirana kod banaka, a zatim su potrošena do kraja 2009. uglavnom na kupnju zemljišta i građevinskih objekata.

Uz izdanje obveznica ugovoren je i kamatni swap, tako da Holding umjesto fiksnih 5,5\% kamata na obveznicu u prvim godinama plaća manju fiksnu kamatnu stopu (za 2008. 3\%, a za 2009. i 20IO. 3,5\%). Za ostale godine od 20II. do 20I7. - Društvo je trebalo plaćati varijabilnu kamatu (prema utvrđenoj formuli) koja se može kretati od najmanje o\% (ugovoreni floor) do najviše 6,4\% (ugovoreni cap). Međutim, zbog pogoršanja kreditnog rejtinga Holdinga, 20Io. je došlo do prestanka swap-a, što je rezultiralo odljevom oko 65,2 milijuna kuna (od čega je 24,5 milijuna kuna trošak u 2009., a 40,6 milijuna kuna teretilo je troškove u 20Io.).

Dodatno čudi i zabrinjava postojeća valutna struktura obveza Holdinga. Čak $88 \%$ duga denominirano je u eurima (preostali je dio u kunama), a svi prihodi ostvareni su u kunama. Takva valutna neusklađenost uzrok je izloženosti Holdinga valutnom riziku. Zbog slabo strukturiranog portfelja duga, financijski rashodi od negativnih tečajnih razlika rastu s 27,5 u 2006. na čak 137,3 mil. kuna 20II. (tablica 3). Pored toga, Holding je izložen i kamatnom riziku jer je $u$ 2OII. oko 57\% njegovih kreditnih obveza vezano uz varijabilne kamatne stope.

Problematičan je nagli rast kratkoročnih kredita. Samo u 20II. Holding se zadužio za novih milijardu kuna, a primici od zaduživanja koristili su se za refinanciranje postojećih dugoročnih obveza. Tako Holdingov problem s obvezama postaje i veći, jer su kamata i glavnica novih (kratkoročnih kredita) postali trošak duga (iako računovodstveno tako ne izgleda). Krajem 20II., u strukturi 2,3 mlrd. kuna dugoročnih kredita, I4\% dospijeva do jedne godine, $48 \%$ od I do 5 godina, a $37 \%$ u roku dužem od 5 godina. ${ }^{3}$

Glavni je problem što će Holdingu za manje od pet godina na naplatu dospjeti obveznica u iznosu od 300 milijuna eura (više od 2,23 mlrd. kuna). Te će se obveze vjerojatno refinancirati novim zaduživanjem. Međutim, upitno je kojim instrumentima i pod kojim uvjetima, jer već sada nije izvjesno može li Holding bez restrukturiranja financirati visoke obveze. Analiza financijskog poslovanja Holdinga pokazuje da uz postojeću nepromijenjenu logiku poslovanja to neće biti moguće.

3 Prema podacima iz bilješki uz konsolidirane financijske izvještaje ZGH-a za 2OII.

\section{ODABRANI FINANGIJSKI POKAZATELJI}

Financijski pokazatelji ukazuju na potrebu hitnog restrukturiranja Holdinga kako bi dospijeće obveznice $u$ 20I7. dočekao spreman i osigurao njihovo refinanciranje po povoljnim uvjetima.

Krenimo redom. U Holdingu je primjetan trend smanjenja udjela kratkotrajne imovine (zalihe, potraživanja, financijska imovina, plaćeni troškovi budućeg razdoblja, nedospjela naplata prihoda i novac na računima i u blagajni) u ukupnoj imovini, što narušava likvidnost. Pored toga, smanjuje se udio kapitala u pasivi, uz povećanje udjela dugoročnih obveza do 2009., a zatimi kratkoročnih obveza do 20II. U strukturi kapitala dominira dug sa 70\% što je izrazito nepovoljno (povoljan je omjer duga i glavnice 60:40, a za poduzeća koja nisu profitno orijentirana čak i 50:50).

Promotrimo poslovanje Holdinga kroz pokazatelje likvidnosti, zaduženosti aktivnosti, ekonomičnosti, profitabilnosti i financijske nesigurnosti.

Likvidnost je sposobnost poduzeća da podmiri kratkoročne obveze iz tekuće aktivnosti. Koeficijent trenutne likvidnosti (postotak kratkoročnih obveza koje je moguće podmiriti najlikvidnijom imovinom - novcem) uglavnom se smanjuje zbog smanjenja novca na računima i u blagajni, te povećanja kratkoročnih obveza. Koeficijent tekuće likvidnosti (omjer kratkotrajne imovine i kratkoročnih obveza), samo u 2007. prešao je vrijednost od 2 što označava primjerenu likvidnost. U ostalim promatranim godinama se smanjuje, a krajem razdoblja ima vrijednost manju od I što je izrazito slabo i pokazuje da je Holding nelikvidan. Koeficijent financijske stabilnosti (omjer dugotrajne imovine i kapitala uvećanog za dugoročne obveze) u posljednje dvije godine veći je od i i ukazuje da Holding dio dugotrajne imovine financira kratkoročnim izvorima (umjesto obrnuto).

Pokazatelji zaduženosti Holdinga također su nepovoljni. Faktor zaduženosti (omjer ukupnih obveza i zadržane dobiti uvećane za amortizaciju) rastao je s I2,97 u 2006. na čak 35,29 u 20II. Taj je rast uzrokovan zaduživanjem i negativnim neto rezultatom.

Koeficijenti obrta su nestabilni. Povećanjem koeficijenta obrta ukupnih kratkotrajnih potraživanja smanjilo se prosječno vrijeme naplate s 205 dana 2006. na 150 dana 2OII., a prosječno vrijeme plaćanja ukupnih kratkoročnih obveza povećano je S I53 na 223 dana. Novčani jaz (razlika između prosječnog trajanja plaćanja obveza i prosječnog vremena naplate potraživanja) povećao se $\mathrm{s}-53$ na +73 , što ukazuje da slaba likvidnost Holdinga nije uzrokovana problemima u naplati potraživanja. 
Do 20II. pokazatelji ekonomičnosti (omjer prihoda i rashoda) prodaje i ukupnog poslovanja Holdinga su zadovoljavajući. Međutim, ekonomičnost ukupnog poslovanja se smanjuje 20Io. i 20II. zbog izrazito slabe ekonomičnosti financiranja.

Pokazatelji profitabilnosti (sposobnost poduzeća da ostvari određenu razinu dobiti u odnosu prema prihodima, imovini ili kapitalu) pokazuju da neto profitna marža Holdinga raste do 2009. nakon čega se naglo smanjuje. Slična je situacija i s ostalim pokazateljima profitabilnosti. Poduzeće u posljednje vrijeme ostvaruje neto gubitak i postaje neprofitabilno.

Rentabilnost vlastitog kapitala (ROE - prinos na vlastiti kapital poduzeća - dobit po kuni uloženog kapitala) od iznimne je važnosti vlasnicima dioničkih društava. Za Holding ne čude relativno niske vrijednosti tog pokazatelja koje se kreću od o,56\% do 2,62\%. Niske vrijednosti mogu se tumačiti visokim troškovima poslovanja i prezaduženošću.

Iako je financijski položaj Holdinga slab, zahvaljujući potpori Grada Zagreba osigurava se kontinuitet poslovanja, a u određenoj se mjeri zadržava i povjerenje vjerovnika. To bi se povjerenje moglo narušiti zbog evidentnih problema u poslovanju i slabljenju financijskih odnosa s Gradom Zagrebom.

\section{OGJENA KREDITNOG RIZIKA I PRINOS NA OBVEZNICU}

Radi procjene kreditnog rizika dodatno ćemo se osloniti na ocjene rizičnosti Holdinga, koje su obavile rejting agencije, u prvom redu Standard \& Poors. Ukratko, veći kreditni rejting označava veću sigurnost dužnika, tj. manji kreditni rizik te manji očekivani prinos za vjerovnika, odnosno manje troškove duga za dužnika. U nastavku pogledajmo rejting ocjene Holdinga od agencija Standard \& Poor's i Moody's.
Kreditni rizik institucija obično je nešto veći od kreditnog rizika države. Tako je i u Hrvatskoj. Kreditni rejting države u promatranom razdoblju se smanjuje, kao i kreditni rejting Grada Zagreba i Holdinga. Kreditni rejting Grada Zagreba nije veći od kreditnog rejtinga države, kao što ni kreditni rejting Holdinga ne prelazi kreditni rejting Grada Zagreba.

Prvi kreditni rejting od agencije S\&P Holding je dobio 2007. Početni rejting Holdinga od BBB označavao je adekvatnu sposobnost plaćanja. Isti rejting imao je i Grad Zagreb, a Republika Hrvatska imala je veći (BBB+). Takav je rejting Holding održao do 2009., kada se smanjuje na BBB- $i$ to zbog rasta duga i slabe likvidnosti uzrokovane gospodarskom krizom. Već 20IO. S\&P smanjuje kreditni rejting Holdinga na BB (s negativnim izgledom). Kreditni rejting Holdinga zapravo je kombinacija vlastitog kreditnog profila (koji S\&P rangira kao B) i „vrlo visoke vjerojatnosti” da će Grad Zagreb kao vlasnik Holdinga pružiti pravovremenu potporu $u$ slučaju financijskih poteškoća. U 2OII. rejting Holdinga dodatno je smanjen (s BB na BB-) zbog visoke zaduženost, neadekvatne likvidnosti i nepredvidive financijske politike. Holding, naime, nema dugoročnu financijsku strategiju.

U studenom 20I2., rejting je smanjen s BB- na B+, što je samo jedan razred više od kategorije za koju postoji „opasnost od nenaplativosti”. Pogoršanje kreditnog profila Holdinga uzrokovano je rastom nelikvidnosti, narušavanjem kvalitete dužničkog portfelja u kojem raste udio kratkoročnog duga, te padom cijena nekretnina. Takva nepovoljna financijska kretanja i financijski pokazatelji utječu i na kretanja prinosa obveznica Holdinga koje kotiraju na međunarodnom tržištu kapitala.

Prinos do dospijeća obveznice Holdinga je nestabilan. Primjetan je blagi porast do sredine 2008., kada prinos naglo raste, vjerojatno zbog smanjenja kreditnog rejtinga. Nakon toga prinos se smanjuje te od kraja 2009. do sredine 20II. fluktuira oko $9 \%$.

Tablica 7.

Kreditni rejting Holdinga, Grada Zagreba i Republike Hrvatske

\begin{tabular}{|c|c|c|c|c|c|c|}
\hline \multirow{2}{*}{ Godina } & \multicolumn{2}{|c|}{ Holding } & \multicolumn{2}{|c|}{ Grad Zagreb } & \multicolumn{2}{|c|}{ RH } \\
\hline & Moody's & $S \& P$ & Moody's & $S \& P$ & Moody's & $S \& P$ \\
\hline 2007. & Baa2 & BBB & Baai & BBB & BaaI & $\mathrm{BBB}+$ \\
\hline 2008. & Ваa2, Ваa3 & BBB & ВаaI, Ваa2 & BBB & BaаI, Baа2 & $\mathrm{BBB}+$ \\
\hline 2009. & Baa3 & BBB, BBB- & Ваa2, Ваa3 & BBB, BBB- & Baа2, Baа3 & $\mathrm{BBB}+, \mathrm{BBB}$ \\
\hline 2010. & Baa3 & BBB-, BB & Baa3 & BBB- & Baa3 & BBB, BBB- \\
\hline 2011. & Baa3 & BB, BB- & Baa3 & BBB- & Baa3 & BBB- \\
\hline 2012. & Baa3 & BB-, B+ & Baa3 & BBB- & Baa3 & BBB- \\
\hline 2013. & $\mathrm{Ba} 2$ & BB-, B+ & Ваa3, Ваг & $\mathrm{BBB}, \mathrm{B}+$ & Baа3, Bai & $\mathrm{BBB}, \mathrm{B}+$ \\
\hline
\end{tabular}

Izvor: Sistematizacija autora na temelju izvještaja rejting agencija Moody's i S\&P. 


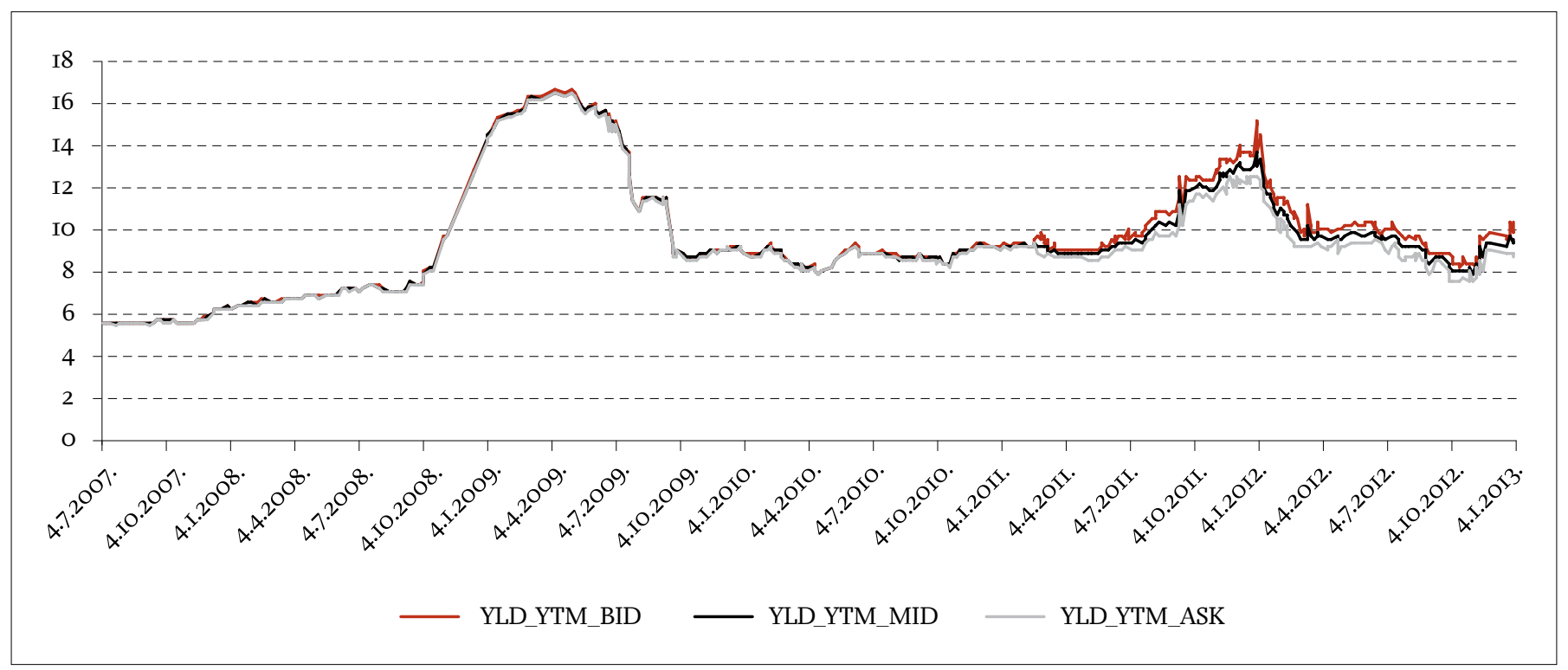

Izvor: Bloomberg, $2 \mathrm{OI3}$.

Zanimljivo je primijetiti značajne varijacije prinosa i povećanje razlike prinosa ponude i potražnje (engl. bid-ask spread) od početka 2OII. do kraja promatranog razdoblja, što ukazuje na nelikvidnost obveznice na sekundarnom tržištu. Razlika prinosa ponude i potražnje rezultat je nepostojanja konsenzusa investitora o kreditnom riziku Holdinga zbog asimetrije informacija. Postojeći vjerovnici vrednuju obveznice znatno više nego potencijalni. Nepostojanje likvidnosti za Holdingovu obveznicu onemogućava donošenje kvalitetnijih zaključaka o kretanju cijene ili prinosa na obveznicu.

\section{ZAKLJUǦAK}

Financijsko poslovanje Holdinga je slabo, a financijski se položaj u posljednje dvije promatrane godine značajno pogoršava. Financijska pozicija Grada Zagreba izložena je visokim rizicima dospijeća financijskih obveza Holdinga. Sredinom 2017. dospijeva glavnica izdanih obveznica, što dodatno usložnjava financijsku poziciju Grada i dovoljan je motiv za nužno restrukturiranje Holdinga.
Prihodi poslovanja Holdinga pokrivaju rashode poslovanja. Međutim, zbog nerazboritog zaduživanja i slabog upravljanja financijama, nagomilane su visoke obveze koje prijete financijskoj stabilnosti Holdinga. Zbog slabih poslovnih rezultata i slabe financijske perspektive nužno je redefinirati ulogu Holdinga $u$ pružanju javnih dobara i usluga. Potrebno je profilirati jasnu misiju i viziju njegova budućeg razvoja, koji bi primarno trebao biti usmjeren na pružanje javnih dobara i usluga.

Potrebno je odvojiti tržišne djelatnosti od djelatnosti koje se odnose na pružanje lokalnih javnih dobara i usluga, za koje može biti opravdano davanje potpora iz Gradskog proračuna. U strukturi obveza, novim zaduživanjima treba povećati udio duga denominiranog u kunama s fiksnom kamatnom stopom i što dužim rokovima dospijeća.

Dio tržišnih djelatnosti nedvojbeno treba privatizirati. Privatizaciju treba dobro pripremiti kako se ne bi obavljala u nepovoljnim tržišnim uvjetima. Zbog slabog financijskog upravljanja nužno je preispitati unutarnju upravljačku organizaciju Holdinga i utvrditi mogućnosti za njeno poboljšanje. 


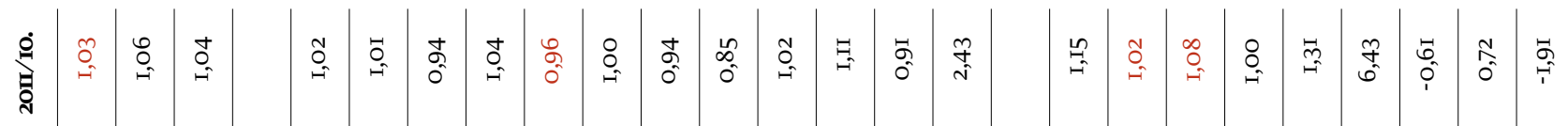

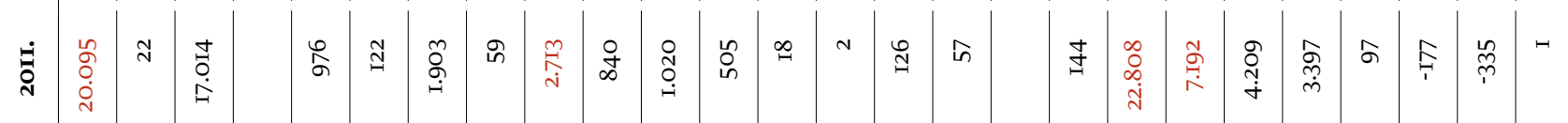

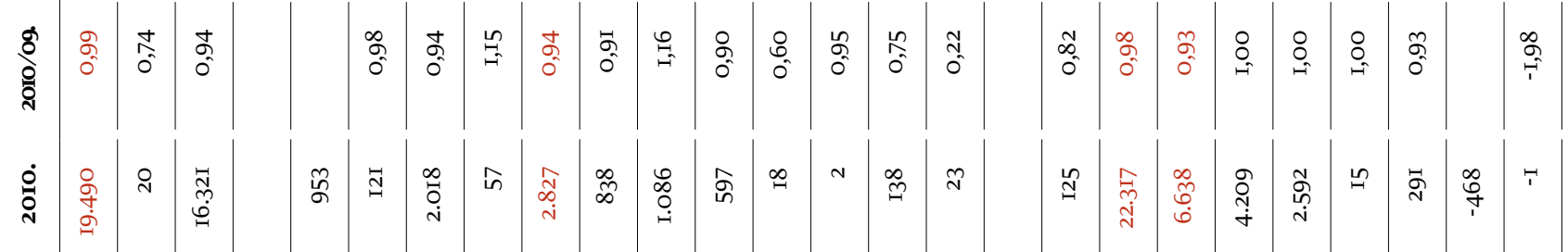
苃

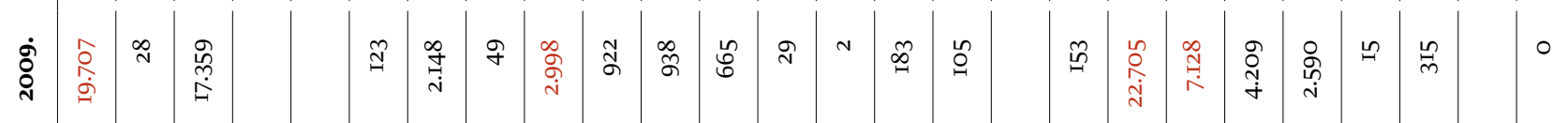

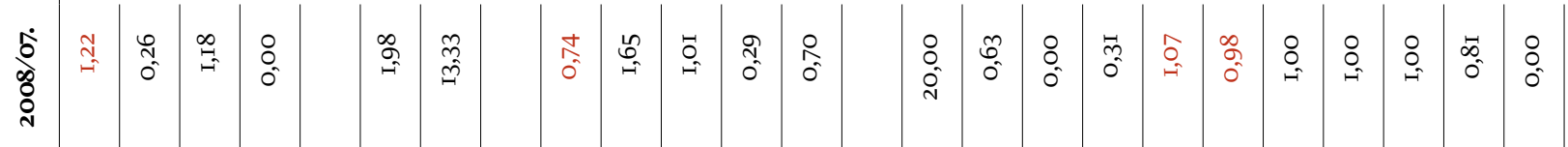

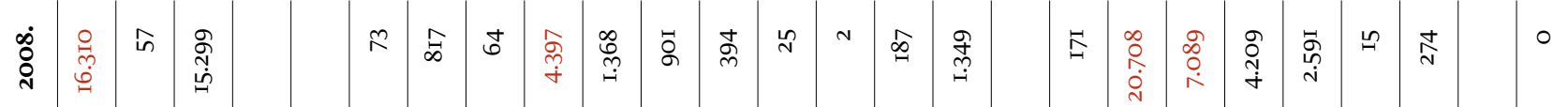

类帝

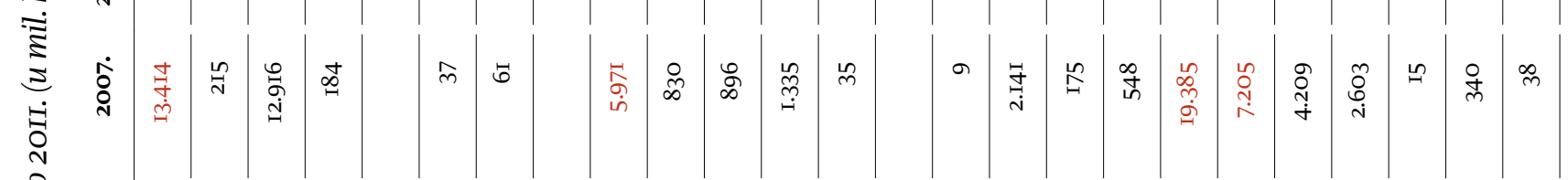

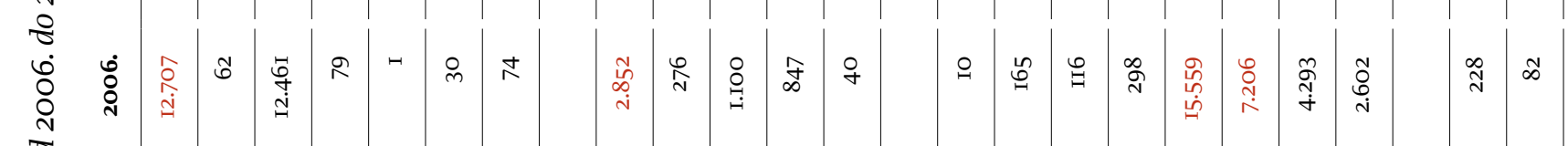

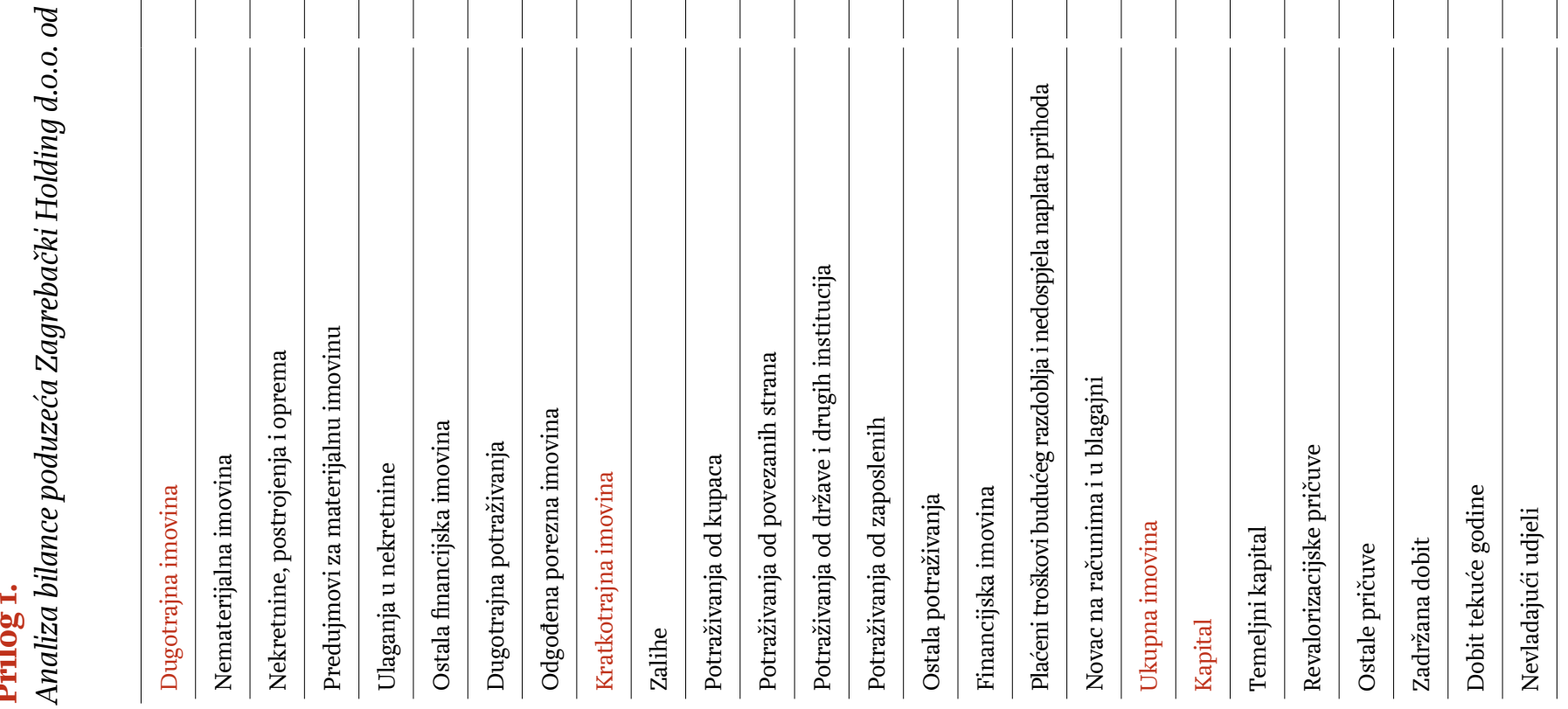




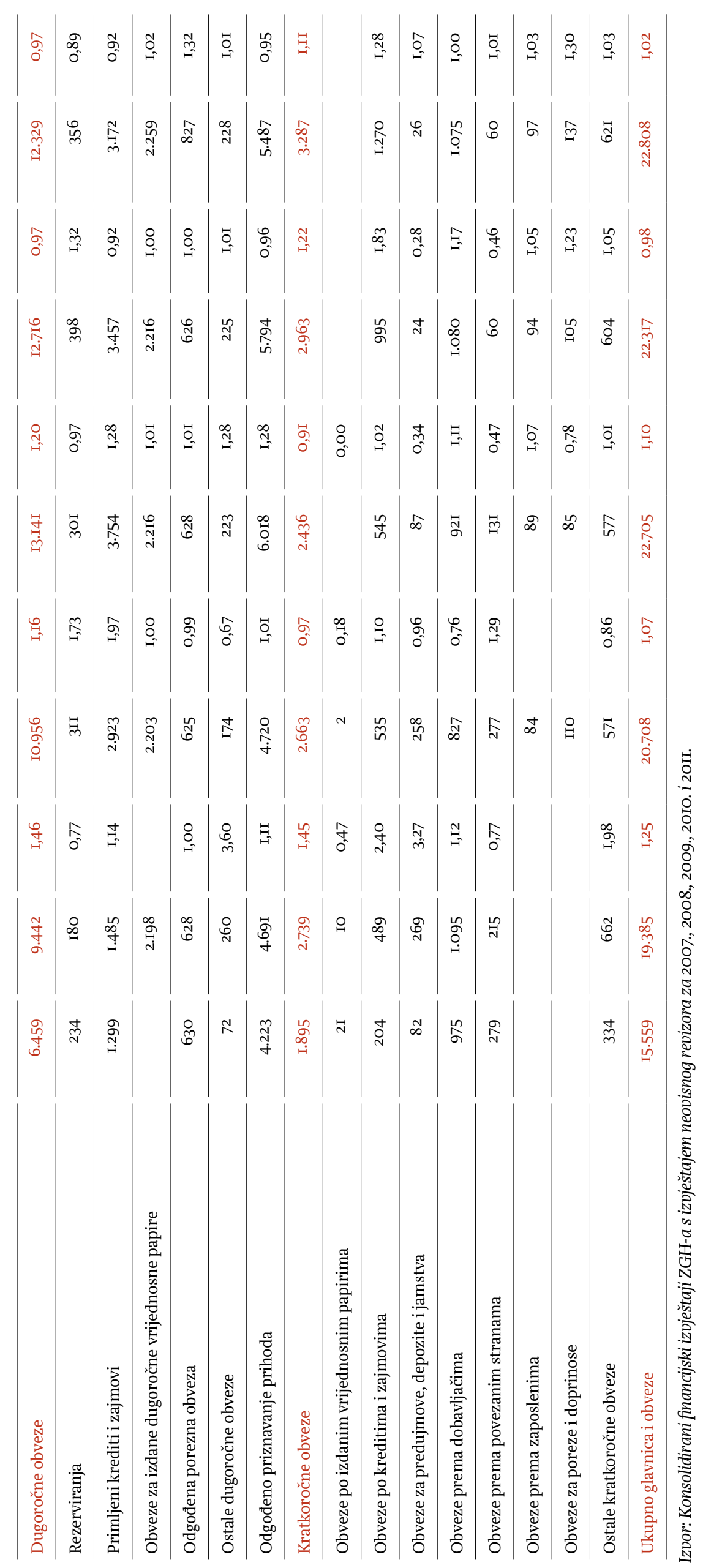


Prilog 2.

Analiza financijskih pokazatelja poduzeća Zagrebački Holding d.o.o. od 20o6. do 201 I.

\begin{tabular}{|c|c|c|c|c|c|c|}
\hline Financijski pokazatelji & 2006. & 2007. & 2008. & 2009 & 2010. & $20 I I$. \\
\hline \multicolumn{7}{|l|}{ Pokazatelji likvidnosti } \\
\hline Koeficijent trenutne likvidnosti & O,I6 & 0,20 & 0,06 & o,o6 & $\mathrm{O}, \mathrm{O} 4$ & 0,04 \\
\hline Koeficijent ubrzane likvidnosti & $\mathrm{I}, 36$ & $\mathrm{I}, 88$ & $\mathrm{I}, \mathrm{I} 4$ & 0,85 & 0,67 & 0,57 \\
\hline Koeficijent tekuće likvidnosti & $\mathrm{I}, 5 \mathrm{I}$ & $2, \mathrm{I} 8$ & $\mathrm{I}, 65$ & $\mathrm{I}, 23$ & 0,95 & 0,83 \\
\hline Koeficijent financijske stabilnosti & 0,93 & $\mathrm{O}, 8 \mathrm{I}$ & 0,90 & 0,97 & I,OI & I,O3 \\
\hline \multicolumn{7}{|l|}{ Pokazatelji zaduženosti } \\
\hline Koeficijent zaduženosti & 0,54 & 0,63 & 0,66 & 0,69 & 0,70 & 0,68 \\
\hline Koeficijent vlastitog financiranja & 0,46 & 0,37 & 0,34 & O,3I & 0,30 & 0,32 \\
\hline Faktor zaduženosti & $\mathrm{I} 2,97$ & I6,I8 & $\mathrm{I} 7,56$ & $\mathrm{I} 7,5 \mathrm{O}$ & $\mathrm{I7,IO}$ & 35,29 \\
\hline Stupanj pokrića & I,O8 & $\mathrm{I}, 24$ & I,II & $\mathrm{I}, \mathrm{O} 3$ & 0,99 & 0,97 \\
\hline \multicolumn{7}{|l|}{ Pokazatelji aktivnosti } \\
\hline Koeficijent obrta ukupne imovine & 0,30 & 0,28 & 0,25 & 0,26 & 0,25 & 0,24 \\
\hline Koeficijent obrta kratkotrajne imovine & $\mathrm{I}, 64$ & 0,92 & $\mathrm{I}, 2 \mathrm{O}$ & I,99 & 1,96 & $2, \mathrm{O} 2$ \\
\hline Koeficijent obrta potraživanja & 1,75 & $\mathrm{I}, 47$ & $2,4 \mathrm{I}$ & 2,43 & 2,22 & 2,40 \\
\hline Trajanje naplate potraživanja & 205,48 & 244,79 & $\mathrm{I} 49,43$ & $\mathrm{I} 48, \mathrm{IO}$ & I6I,87 & 149,76 \\
\hline Trajanje plaćanja obveza & 152,92 & $\mathrm{I} 88, \mathrm{O} 2$ & 194,45 & 159,62 & 193,62 & 222,65 \\
\hline \multicolumn{7}{|l|}{ Pokazatelji ekonomičnosti } \\
\hline Ekonomičnost ukupnog poslovanja & $\mathrm{I}, \mathrm{O} 2$ & I,OI & I,OI & I,OI & 0,92 & 0,94 \\
\hline Ekonomičnost prodaje & $\mathrm{I}, \mathrm{O} 2$ & $\mathrm{I}, \mathrm{O} 2$ & I,OI & $\mathrm{I}, \mathrm{O} 5$ & 0,98 & I,OI \\
\hline Ekonomičnost financiranja & $\mathrm{I}, \mathrm{O} 3$ & 0,84 & I,06 & 0,53 & 0,26 & 0,22 \\
\hline \multicolumn{7}{|l|}{ Pokazatelji profitabilnosti } \\
\hline Neto marža profita & $\mathrm{O}, \mathrm{O} 4$ & 0,05 & 0,06 & $\mathrm{O}, \mathrm{O} 7$ & $\mathrm{O}, \mathrm{OO}$ & 0,03 \\
\hline $\mathrm{ROA}$ & $\mathrm{O}, \mathrm{OI}$ & $\mathrm{O}, \mathrm{OO}$ & $\mathrm{O}, \mathrm{OO}$ & $\mathrm{O}, \mathrm{OO}$ & $-0,02$ & $-\mathrm{O}, \mathrm{OI}$ \\
\hline $\mathrm{ROE}$ & $\mathrm{O}, \mathrm{OI}$ & $\mathrm{O}, \mathrm{OI}$ & $\mathrm{O}, \mathrm{OO}$ & $\mathrm{O}, \mathrm{OI}$ & $-0,07$ & $-0,05$ \\
\hline Altmanov zbrojni pokazatelj financijske nesigurnosti & 0,67 & 0,63 & 0,49 & 0,40 & 0,26 & 0,26 \\
\hline $\mathrm{XI}_{\mathrm{I}}$ & o,06 & O,I7 & o,08 & $\mathrm{O}, \mathrm{O} 2$ & -O,OI & $-0,03$ \\
\hline $\mathrm{X} 2$ & O,OI & $\mathrm{O}, \mathrm{O} 2$ & O,OI & O,OI & O,OI & -O,OI \\
\hline $\mathrm{X} 3$ & O,OI & $\mathrm{O}, \mathrm{OI}$ & $\mathrm{O}, \mathrm{O} 2$ & $\mathrm{O}, \mathrm{O} 2$ & $\mathrm{O}, \mathrm{OO}$ & O,OI \\
\hline $\mathrm{X} 4$ & 0,86 & 0,59 & 0,52 & 0,46 & 0,42 & 0,46 \\
\hline $\mathrm{X} 5$ & O,OI & $\mathrm{O}, \mathrm{OO}$ & $\mathrm{O}, \mathrm{OO}$ & O,OI & $\mathrm{O}, \mathrm{OO}$ & $\mathrm{O}, \mathrm{OO}$ \\
\hline
\end{tabular}

Izvor: Konsolidirani financijski izvještaji ZGH-a s izvještajem neovisnog revizora za 2007., 2008., 2009., 20I0. i 2011. 
Agencija za zaštitu tržišnog natjecanja (AZTN), 2007. Godišnje izvješće o radu Agencije za zaštitu tr- žišnog natjecanja za 2006. godinu. [pdf] Zagreb: Agencija za zaštitu tržišnog natjecanja. Dostupno na: <http:// www.aztn.hr/uploads/documents/tn/godisnja izvjesca/godisnje_izvjesce_AZTN_za_20o6.pdf>.

Beard Group, 20Io. Zagrebacki Holding: S\&P Lowers Corporate Credit Rating to 'BB'. Troubled Company Reporter: Europe, [e-journal] II(227). Dostupno na: < http:// bankrupt.com/TCREUR_Public/IOIII7.mbx>.

Beard Group, 20II. Zagrebacki Holding: S\&P Lowers Issuer Credit Rating to 'BB'. Troubled Company Reporter: Europe, [e-journal] I2(236). Dostupno na: 〈http:// bankrupt.com/TCREUR_Public/IIII29.mbx>.

Državni ured za reviziju, 20I2. Izvješće o obavljenoj reviziji - Zagrebačko holding d.o.o. Zagreb. Zagreb: Državni ured za reviziju.

Reuters, 2012. TEXT-S\&P: Zagreb's rating unaffected by finance ministry dispute [online]. Dostupno na: <http://www.reuters.com/article/20I2/IO/I9/ idUSWNA798820I2IOI9>.

Reuters, 20I2a. TEXT-S\&P cuts Zagrebacki Holding rating to 'B+', outlook is negative [online]. Dostupno na:
<http://www.reuters.com/article/2OI2/II/27/ idUSWNAoo6320I2II27>.

Standard \& Poor's, 2009. Izvješće o ocjeni kreditnog rejtinga poduzeća Zagrebački Holding d.o.o. [online]. Dostupno na: <www.standardandpoors.com/ratings/ articles/en/us/?assetID=I245193589485>.

Vodoprivreda Zagreb. Privatizacija trgovačkog društva Vodoprivreda Zagreb d.d. [online]. Dostupno na: 〈http://www.vzg.hr/privatizacija.htm〉.

Zagrebački holding. Konsolidirani financijski izvještaji Zagrebačkog Holdinga s izvještajem neovisnog revizora za 2007., 2008., 2009., 2OIO. i 20II. Zagreb: Zagrebački holding.

Zakon o izmjenama i dopunama Zakona o vodama, NN I50/O5. Zagreb: Narodne novine.

Zakon o komunalnom gospodarstvu, NN 36/95, 70/97, I28/99, 57/OO, I29/OO, 59/OI, 26/O3, 82/O4, IIO/O4, I78/04, 38/o9, 79/o9, I53/o9, 49/II, 84/II i 90/II. Zagreb: Narodne novine.

Zakon o lokalnoj i područnoj (regionalnoj) samoupravi, NN 33/OI, 60/OI, I06/O3, I29/O5, I09/O7, I25/O8, 36/og i 150/II. Zagreb: Narodne novine.

Zakon o vodama, NN IO7/95. Zagreb: Narodne novine.

Zakon o zaštiti tržišnog natjecanja, NN 79/og. Zagreb: Narodne novine. 